\title{
Managerial Deficiencies and Teachers' Job Accomplishment in Public Primary Schools, Delta State, Nigeria
}

ATAINE Juliet Asoro: Head Teacher at State Universal Primary Education Board, Delta State, Nigeria.

\begin{abstract}
This study investigated managerial deficiencies and teachers' job accomplishment in public primary schools. It is a correlational survey of ex-post facto design. The population involves fifteen thousand eight hundred and sixty-seven $(15,867)$ head teachers and teachers of primary schools in Delta state, that is 1,113 and 14,754 head teachers and teachers respectively. Purposive sampling technique was adopted to select 1,586 respondents, representing $10 \%$ of the entire population. Self-structured questionnaire titled Managerial Deficiencies and Teachers Job Accomplishment Questionnaire (MDTJAQ) was used to solicit information from respondents. Instrument was validated through face/content validity and thereafter subjected to split-halves reliability using 30 respondents not used for the core study. A coefficient of .76 was obtained showing a high reliability co-efficient. Data obtained was analysed using mean rating and standard deviation to answer research questions with benchmark of 2.50 while hypothesis was tested using Pearson $r$ at .05 level of significance. Finding shows that managerial deficiencies was significantly related to teachers' job accomplishment. Arising from the findings it was recommended among others that State Universal Primary Education Board should enlighten government on the role of primary school and the need to invest money on primary education for optimum result.
\end{abstract}

Key words: Managerial deficiencies, Teachers' job accomplishment, Public primary schools and delta state.

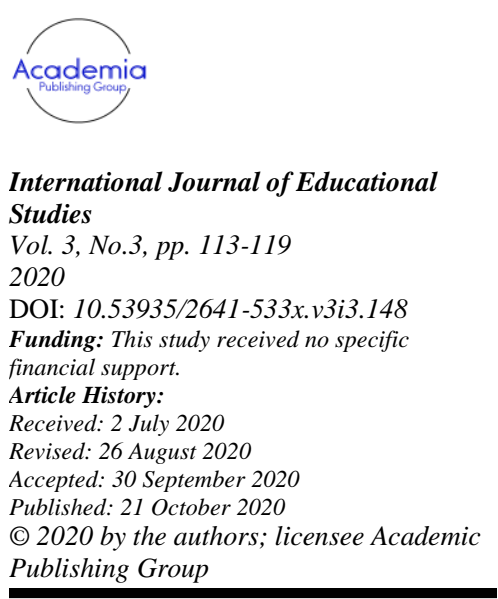

| 113

\section{Introduction}

Origin of managerial deficiencies facing head teachers in primary schools can be traced to sources like school authorities, teachers, pupils and even school environment. For instance, school authorities in most cases do not provide adequate funding, facilities and staff for effective teaching thereby bringing in laxities among the school products. School environment is a reflection of the totality of Nigerian society. The behaviours of Nigerians themselves seems not be worthy of emulation by children. Yet school children will imitate their leaders, parents, brothers or sisters. wrote that in 1955 every school aged children went to school, learned without paying school fees. Pupils were educated by committed teachers who were knowledgeable, they time and expertise were dedicated to teaching and learning. School surroundings and infrastructure were attractive and learner friendly. Teaching/learning facilities were provided in adequate quantity. Teachers took pride in their own ability to improvise teaching aid, children learned how to read, write, calculate and they were also able to fit into the world of work. It implies that excellence of primary school education rested on good administration involving the local communities, school authorities, adequate funding, facilities and sufficient teachers, together with interested parents supplying children's material needs and giving home training to supplement teachers' effort at school.

In spite of the roles of education generally, Ajayi (2014) reported that there are various managerial deficiencies such as poor funding, poor educational infrastructure such as inadequate classrooms, low quality staff, and learning environment that is polluted. School where these amenities were not significantly 
provided, to administer school diligently, heads teachers' effort will be disenchanted. Probable outcomes of this kind of situation comprise unruly and disorderly pupils, non-literate population, an unresponsive teaching workforce and hinders the fulfilment of educational objectives (Ikegbusi, 2014). Stressing on what head teachers go through in school, Peretomode (2003) explained that school administration is a component part of management concerned with facilitating accomplishment of organisational objectives like school, through systematic management of constraints and careful utilization of available limited resources like human, material and finance. Okeke (2013) stated that school administration involves provision and maintenance of the necessary manpower to those who teach children with a view of bringing about the desired change in the child's conduct. Today, school heads seem to face numerous managerial deficiencies like inadequate staffing, funding to repair schools and payment of staff salaries, accommodation for pupils, among others which militate against operative running of their schools. Where school heads fail to arrest these circumstances and problems, smooth running of primary school is acknowledged.

Facilities as managerial deficiencies include all the buildings and equipment in schools that aid teaching and learning. Administration of primary schools are becoming difficult due to inadequate infrastructural facilities (Alagbu, 2003). Alagbu explained further that large number of schools suffer an immense deprivation of facilities that aid teaching and learning. Teachers' ineffectiveness in delivering their duties could be attributed to inadequate provision of infrastructural facilities for effective teaching and learning. This kind of situation has consistently presented enormous challenges to school heads. Earthman, Cash, and Van Berkum (2016) found that $11^{\text {th }}$ grade pupils in standard buildings scored higher as measured by the Comprehensive Test of Basic Skills than did their peers attending schools in substandard facilities. Cash (2013) found that when socio-economic factors were constant, facility condition had a significant correlation with teachers and pupils' achievement. Specifically, Cash (2013) found that air conditioning, absence of drawings, condition of science laboratories, locker accommodations, condition of classroom furniture, wall colour and acoustic levels correlated with teachers and student achievement at a significant level. Schneider (2013) reports that teachers list environmental problems such as poor indoor air quality, noise, low lighting as well as 25 percent indicating that they have taught in non-instructional areas such as hallways or even closets. Becker (2011) notes that adequate space with comfortable temperature, furnishings and lighting will increase the satisfaction of occupants and increase individual capabilities as a result.

According to Obi (2017) staffing is the process of ensuring that competent employees are selected, developed and rewarded for accomplishing the organization's objective. He went further to say that human resources are the lifeblood of an institution. Odia and Omofonmwan (2007) argue intensely that acute shortage of teachers can result in poor outcome in teaching and learning. They also called for a revitalisation of the education programmes in Nigeria through research, manpower training and development. Staffing is seen by many researchers as a vital part of the functioning of any organization, including a school. Nel (2012) posits that staffing is a technique used by an organisation to place the right person in the right position. According to Ikegbusi (2014) availability of teachers is the prime factor of school administration. Thus for proper school administration and achievement of educational objectives, quality and efficiency staff are needed. UNESCO (2005) reported that, the lack of science and technology teachers is particularly striking and in an attempt to solve the problem, non-teachers are sometime called in such as the health professional to teach biology in central Africa, African Republic, these evidence were revealed from the general problems in teacher training for the high level expects, meeting on UNESCO Teacher. Cramer and Spalding (2006) reported that shortage of qualified teacher is due to lack of full trained teacher and problem has increased. This is due to the increased birth rate, have brought floods of new children into the school. showed that, the world is facing a shortage of qualified teachers which negatively impact on pupils' academic achievement. Ingersoll (2013) data shows that, one-third of all lessons in grade $7-12$ are taught by non -specialists. According to Ogba and Igu (2014) poor funding is one of the greatest constraint of school management and administration. The extent to which sufficient educational programmes are attained depends largely on economic provisions aiding the programme. Inadequate financial resources often lead to teachers teaching large classes, inadequate libraries with limited instructional materials, poorly constructed buildings and poorly trained teachers. Insufficient funds to maintain schools and pay teachers' salaries are among other factors that militate against the smooth administration of education as most school heads have cried out. The lack of adequate funding to education have put enormous degree pressure on school

Vol. 3, No.3, pp. 113-119

2020

DOI: $10.53935 / 2641-533 x . v 3 i 3.148$ Funding: This study received no specific financial support. Received: 2 July 2020

Revised: 26 August 2020

Accepted: 30 September 2020

Published: 21 October 2020

(C) 2020 by the authors; licensee Academic Publishing Group

| 114

International Journal of Educational
Studies
Vol. 3 , No.3, pp. 113-119
2020
DOI: $10.53935 / 2641-533 x . v 3 i 3.148$
Funding: This study received no specific
financial support.
Article History:
Received: 2 July 2020
Revised: 26 August 2020
Accepted: 30 September 2020
Published: 21 October 2020
○) 2020 by the authors; licensee Academic
Publishing Group
Puish


administrators, this is why Anderson and Lamby (2015) pointed out that there is a high degree of pressure on school heads to raise funds so that their schools are fully efficient. A teacher who has not received salary for months will decline his/her job accomplishment thus, putting pupils' academic achievement into jeopardy.

Moja (2010) discovered that building of classroom has not kept up with increased enrolment in all levels of education in Nigeria. Worst affected are primary and secondary schools where classes are offered in the open air. In several secondary schools, as many as four classes are accommodated in one classroom and these are classes that are already overcrowded and in poor state of repairs. Ogbonnaya (2015) contends that education sector competes with the industrial, health, agriculture, communication sectors of the economy and as such demands effective funding from government. Nwadiani (2010) noted that classrooms, furniture, equipment and other instructional materials are very inadequate due to underfunding. According to Etuk (2011) pupils are not provided with adequate and relevant learning facilities in terms of classrooms, desks, books, libraries as well as good food, health, extra class activity facilities due to inadequate financial resources. result indicated that organized communities such as parent teachers associated, age grades, did not make a significant contribution in funding education in the area of the study. However, women organization and religious organization made minimal financial contributions in the provision of secondary education in the area.

\subsection{Statement of the Problem}

As a head teacher in one of the primary schools in Delta State Nigeria, it has been observed that school heads are under pressure to initiate innovative management practices that are geared towards improvement of teaching and learning as measured through enhanced teachers job accomplishment. Studies have also shown that school heads are expected to improve their management practices by becoming educational visionaries, instructional and curriculum leaders, assessment experts, to mention but a few. In discharging their managerial duties, it has been discovered by the researcher that most school heads encounter managerial deficiencies such as inadequate facilities, inadequate staffing, inadequate funding, which have hindered the smooth running of the school and significantly affected teachers job accomplishment. As such teachers are no longer committed to their job. However, teachers' job accomplishment has also been identified as one of the critical factors in the success and future of the educational system. Absence of obligation on the part of the teachers has been seen as an elucidation for a diversity of ills, among which are absenteeism, irregularities in classroom and indiscipline among teachers. From foregoing it becomes imperative that teachers' job accomplishment could be as a result of managerial deficiencies experience by school heads. This study thus, aimed at identifying managerial deficiencies in public primary schools, level of teachers' job accomplishment and how inadequate funding, facilities and staffing as managerial deficiencies influence teachers' job accomplishment.

\subsection{Research Questions}

1. What are managerial deficiencies facing school heads in public primary schools

2. What is the level of teachers' job accomplishment?

3. What is relationship between managerial deficiencies and teachers' job accomplishment?

\subsection{Hypothesis}

1. Managerial deficiencies are not significantly related to teachers' job accomplishment.

International Journal of Educational Studies

Vol. 3, No.3, pp. 113-119

2020

DOI: $10.53935 / 2641-533 x . v 3 i 3.148$

Funding: This study received no specific

financial support.

Article History:

Received: 2 July 2020

Revised: 26 August 2020

Accepted: 30 September 2020

Published: 21 October 2020

(C) 2020 by the authors; licensee Academic Publishing Group

\section{Methodology}

This study is a correlational survey of ex-post facto design with a population involving fifteen thousand eight hundred and sixty- seven $(15,867)$ head teachers and teachers of primary schools in Delta state, that is 1,113 and 14,754 head teachers and teachers respectively. Out of this population, a purposive sampling technique was adopted to select 1,586 respondents, representing $10 \%$ of the entire population. Self-structured questionnaire titled Managerial Deficiencies and Teachers Job Accomplishment Questionnaire (MDTJAQ) clustered in two sections was used to solicit information from respondents. The instrument was validated through face/content validity to ensure that instrument measure what it intend to measure. Thereafter the instrument was subjected to split-halves reliability test using 30 respondents not 
used for the core study. The instrument was correlated using Pearson Product Moment Correlation and a coefficient of .76 was obtained showing a high reliability index. Data obtained was analysed using mean rating and standard deviation to answer research questions with benchmark of 2.50 while hypothesis was tested using Pearson $r$ at .05 level of significance.

\section{Presentation of Result and Discussion}

Research Question 1: What are managerial deficiencies facing school heads in public primary schools?

Table-1. Mean rating and SD analysis on managerial deficiencies facing school heads in public primary schools.

\begin{tabular}{lllll}
\hline S/N & Managerial deficiencies & Mean & SD & Decision \\
\hline 1. & Inadequate funding & 3.09 & 0.81 & + \\
2. & Inadequate infrastructural facilities & 2.99 & 0.84 & + \\
3. & Inadequate teaching staff & 2.70 & 0.80 & + \\
4. & Negative attitudes of teachers & 2.98 & 0.82 & + \\
5. & Indiscipline among pupils & 3.05 & 0.84 & + \\
6. & Low quality intakes & 2.94 & 0.80 & + \\
7. & Prevalence of examination malpractice & 2.99 & 0.83 & + \\
8. & Incidences of wastage & 3.02 & 0.81 & + \\
9. & Inappropriate curriculum & 2.71 & 0.89 & + \\
10. & Inadequate payment of teachers salary & 2.95 & 0.88 & + \\
\hline Keys:+=Positive & & & &
\end{tabular}

Keys: += Positive, - =Negative, Mean Benchmark 2.50

Table 1 shows mean rating and SD analysis on managerial deficiencies facing school heads in public primary schools. Result revealed that respondents agree on all items with mean rating above 2.50 benchmark. It implies that managerial deficiencies facing school heads involves inadequate funding, inadequate infrastructural facilities, inadequate teaching staff, negative attitudes of teachers, indiscipline among pupils, low quality intakes, prevalence of examination malpractice, and incidences of wastage, inappropriate curriculum and inadequate payment of teachers' salary.

Research Question 2: What is the level of teachers' job accomplishment?

Table-2. Mean rating and SD analysis on level of teachers' job accomplishment.

\begin{tabular}{|c|c|c|c|c|}
\hline $\mathbf{S} / \mathbf{N}$ & Teachers' job accomplishment & Mean & SD & Decision \\
\hline 1 & Caution pupils who display undesirable behaviour & 2.99 & 0.80 & + \\
\hline 2 & Inculcate discipline in pupils & 2.98 & 0.79 & + \\
\hline 3 & Takes pupils class attendance & 3.05 & 0.81 & + \\
\hline 4 & Carry out other duties assigned by school head & 2.97 & 0.82 & + \\
\hline 5 & Cover scheme of work before the end of the term & 3.03 & 0.84 & + \\
\hline 6 & Creating conducive classroom environment & 3.02 & 0.79 & + \\
\hline 7 & Following scheme of work in teaching & 3.00 & 0.82 & + \\
\hline 8 & Updating lesson note & 2.70 & 0.82 & + \\
\hline 9 & Participate in keeping school environment clean & 2.82 & 0.83 & + \\
\hline
\end{tabular}

Keys: += High, - =Low, Mean Benchmark 2.50

Table 2 shows mean rating and SD analysis on level of teachers' job accomplishment. Result revealed that respondents agree on all items with mean rating above 2.50 benchmark. It shows that teachers' job accomplishment was high on caution pupils who display undesirable behaviour, inculcate discipline in pupils, takes pupils class attendance, carry out other duties assigned by school head, cover scheme of work before the end of the term, creating conducive classroom environment, following scheme of work in teaching, updating lesson note and participate in keeping school environment clean Research Question 3: What is relationship between managerial deficiencies and teachers' job accomplishment?

International Journal of Educational Studies 2020

DOI: $10.53935 / 2641-533 x .13 i 3.148$ Funding: This study received no specific financial support. Article History:

Recived: 26 Auly 2020

26 August 2020

Accepted. 30 September 2020

2020 by the authors; licensee Academic Publishing Group 
Table-3. Mean rating and SD analysis on managerial deficiencies and teachers' job accomplishment.

\begin{tabular}{|c|c|c|c|c|}
\hline Variables & Mean & SD & $\mathbf{r}$ & $\mathbf{r}^{2}$ \\
\hline Managerial Deficiencies & 28.12 & 2.80 & 0.651 & 0.424 \\
\hline Teachers' job accomplishment & 22.73 & 3.92 & & \\
\hline
\end{tabular}

Table 3 shows mean rating and SD on managerial deficiencies and teachers' job accomplishment. Result revealed mean rating of $28.12, \mathrm{SD}=2.80$ for managerial deficiencies and 22.73, $\mathrm{SD}=3.92$ for teachers' job accomplishment. R-value of .651 shows positive relationship between managerial deficiencies and teachers' job accomplishment. $r^{2}$ shows that managerial deficiencies influence teachers job accomplishment by $42.4 \%$

Hypothesis 1: Managerial deficiencies are not significantly related to teachers' job accomplishment.

\begin{tabular}{llll}
\multicolumn{2}{c}{ Table-4. Pearson (r) Analysis of managerial deficiencies and teachers' job accomplishment } \\
\hline Managerial deficiencies & $\begin{array}{l}\text { Managerial } \\
\text { deficiencies }\end{array}$ & $\begin{array}{l}\text { Teachers' job } \\
\text { accomplishment }\end{array}$ \\
& Pearson Correlation & 1 & $0.651^{*}$ \\
& Sig. (2-tailed) & & 0.480 \\
$\mathrm{~N}$ & 793 & 793 \\
Teachers' job accomplishment Pearson Correlation & $0.651^{*}$ & 1 \\
& Sig. (2-tailed) & 0.480 & 793 \\
\hline N & 793 &
\end{tabular}

Table 4 shows Pearson (r) Analysis of managerial deficiencies and teachers' job accomplishment. The result revealed a strong positive relationship between managerial deficiencies and teachers' job accomplishment with $\mathrm{r}=.651$ and significance with $\mathrm{p}$-value $=.480$. Thus, relationship between Managerial deficiencies and teachers' job accomplishment is significant.

\section{Discussion of Results}

Research question 1 revealed that managerial deficiencies facing school heads involves inadequate funding, infrastructural facilities, teaching staff, payment of teachers' salary negative attitudes of teachers, indiscipline among pupils, low quality intakes, prevalence of examination malpractice, incidences of wastage, and inappropriate curriculum. This shows that school heads are saddled with managerial deficiencies which affect their job. This finding is in agreement with Ajayi (2014) who reported of public crises of various dimensions such as poor funding, poor educational infrastructure which include inadequate classrooms, inadequate and low quality teachers, and polluted learning environment. Keller (2013) posits that insufficient funds to maintain schools and pays teachers' salaries are among other factors that militate against the smooth administration of schools. Ogba and Igu (2014) who revealed that one of the biggest lapses of school management and administration is poor funding. Anderson. (2015) who revealed that administrative lapses facing school principals are not numerous they range from inadequate inspection/supervision, inadequate staffing, inadequate communication, indiscipline. who argued intensely that acute shortage of teachers can result in poor outcome in teaching and learning.

Research question 2 revealed that teachers' job accomplishment was high on caution pupils who display undesirable behaviour, inculcate discipline in pupils, takes pupils class attendance, carry out other duties assigned by school head, cover scheme of work before the end of the term, creating conducive classroom environment, following scheme of work in teaching, updating lesson note and participate in keeping school environment clean. This finding clearly show that teachers were committed to their duties and carry out their task diligently. This finding agrees with Tsui and Cheng (2009) who stated that teachers' commitment has been found to be a critical predictor of teachers' work performance as well as having an important influence on students' achievement, and attitudes toward school. Day (2004) who reported that teaching is a profession that requires personal commitment to maintain enthusiasm for being actively involved in the work. Swarnalatha (2016) who discovered that commitment requires acquisition of the

Studies

2020

DOI: $10.53935 / 2641-533 x . v 3 i 3.148$ Funding: This study received no specific financial support.

Article History:

Revised: 26 August 2020

Accepted: 30 September 2020

Published: 21 October 2020

(C) 2020 by the authors; licensee Academic Publishing Group 
special knowledge that characterizes a particular profession and application of that knowledge to achieve certain ends.

Research question 3 and hypothesis 1 revealed that managerial deficiencies was significantly related to teachers' job accomplishment. This finding could be as a result that teachers' duties could be influenced directly or indirectly by managerial deficiencies. This finding supports (Ingersoll, 2013) whose data shows that, one third of all lessons in grade $7-12$ are taught by non -specialists. Ogbonnaya (2015) who contends that education sector competes with the industrial, health, agriculture, communication sectors of the economy and as such demands effective funding from government. Obadara (2016) who reported that some extraneous variables sometimes interfere with the plans and patterns of operation within the school, the teachers' personality, his attitude to work, motivation, discipline, student background and environment which would individually or collectively have either positive or negative effects on the school system and its end results.

\section{Conclusion}

Conclusively, school heads experience managerial deficiencies facing school heads involves inadequate funding, infrastructural facilities, teaching staff, payment of teachers' salary negative attitudes of teachers, indiscipline among pupils, low quality intakes, prevalence of examination malpractice, incidences of wastage, and inappropriate curriculum, these deter their duties. Teachers' job accomplishment was high on caution pupils who display undesirable behaviour, inculcate discipline in pupils, takes pupils class attendance, carry out other duties assigned by school head, cover scheme of work before the end of the term, creating conducive classroom environment, following scheme of work in teaching, updating lesson note and participate in keeping school environment clean. Teachers' job accomplishment was high from data analysis but it being influenced by managerial deficiencies that school heads experience.

\section{Recommendations}

1. State Universal Primary Education Board should enlighten government on the role of primary school and the need to invest money on primary education for optimum result.

2. Facilities both physical and instructional should be made available in schools. This will help realize the objectives of primary education.

3. Teachers in primary schools should be encouraged to improve on their job accomplishment.

4. Delta state government through State Universal Primary Education Board should identify managerial deficiencies facing school heads and find a lasting solution to it.

\section{References}

Ajayi, T. (2014). Resource factors as correlate of secondary school effectiveness in Ekiti state. Nigerian.

Alagbu, C. N. (2003). A comparative study of the administrative and organization of Federal and State secondary schools in Anambra state. Unpublished MEd Thesis. Ahmadu Bello University, Zaria.

Anderson, I., \& Lamby, J. (2015). Managing finance and external relations in South African schools. London: The Commonwealth Secretariat.

Anderson., W. U. (2015). Community participation in the provision of infrastructural facilities in secondary schools. Pretoria: Unity Press.

Becker, F. D. (2011). Workspace: Creating environments in organizations. New York: Praeger Publishers.

Cash, C. S. (2013). Building condition and student achievement and behaviour. Unpublished Doctoral Dissertation, Virginia Polytechnic Institute and State University, Blacksburg, VA.

Cramer, J., \& Spalding, B. (2006). Contemporary education. USA: Harcourt Brace and World Inc.

Day, C. (2004). A passion for teaching. London: Routledge Falmer.

Earthman, G. I., Cash, C. S., \& Van Berkum, D. (2016). Student achievement and behaviour and school building condition. The Journal of School Business Management, 8(3), 26-27.

Etuk, P. K. (2011). Educational financing issues and perspectives: Cameroon Press Print Ltd.

Ikegbusi, N. G. (2014). Teachers' tortious liabilities to students as a correlate of their discipline in Anambra state secondary schools. Unpublished PhD Dissertation. Nnamdi Azikiwe University, Awka.

Ingersoll, R. (2013). Is there really a teacher shortage? A research report co-sponsored by center for the study of teaching and policy and the consortium for policy research in education settle. Washington, DC: Center for the Study of Teaching and Policy.

Keller, B. (2013). Question of teacher turnover speeches research interest. Education Weekly, 27(33).

Moja, R. U. (2010). Cost of education in Nigeria. Jos: Malik Publishers.

Nel, P. S. (2012). Human resources management (8th ed.). Cape Town: Oxford Press. 
Nwadiani, M. (2010). Educational management for Sub-Saharan Africa. Benin City: Nigerian Society for Educational Planning in Collaboration with Monose Amalgamates.

Obadara, B. (2016). Fundamental of educational administration. Lagos: Gafet Publication.

Obi, E. (2017). Educational management: Theory and practice. Enugu: Jamoe Enterprise.

Odia, L., \& Omofonmwan, S. (2007). Educational system in Nigeria problems and prospects. Journal of Social Sciences, 14(1), 86-85.

Ogba, F., \& Igu, N. (2014). Realizing quality education in Nigeria: The need to revitalize secondary education. Journal of Educational Research, 2(3), 57-64.

Ogbonnaya, M. O. (2015). Foundation of education finance. Nsukka: Hallman Publishers.

Okeke, B. S. (2013). Teaching in Nigeria: A case for professionalization. Onitsha: University Pub. Co.

Peretomode, V. F. (2003). Introduction to educational administration, planning and supervision. Lagos: Jopa Press Ltd.

Schneider, F. (2013). Elementary school administration. Columbus, Ohio: Charles Merrill Publishing Co.

Swarnalatha, S. S. (2016). Work commitment of secondary school teachers. The International Journal of Indian Psychology, 3(4), 8489.

Tsui, K. T., \& Cheng, Y. C. (2009). School organisational health and teacher commitment: A contingency study with multi-level analysis. Educational Research and Evaluation, 5(3), 249-268.

UNESCO. (2005). Summary from UNESCO EFA monitoring report education for all. Paris: UNESCO.

International Journal of Educational Studies

Vol. 3, No.3, pp. 113-119

2020

DOI: $10.53935 / 2641-533 x . v 3 i 3.148$

Funding: This study received no specific

financial support.

Article History:

Received: 2 July 2020

Revised: 26 August 2020

Accepted: 30 September 2020

Published: 21 October 2020

(C) 2020 by the authors; licensee Academic

Publishing Group

| 119 